\title{
Thermodynamics of ortophosphoric acid adsorption under static conditions
}

\author{
Vira Sabadash, Jaroslaw Gumnitsky \\ Department of Ecology and Sustainable Environmental Management, Lviv Polytechnic National University, \\ UKRAINE, Lviv, 12, S.Bandery St., 79013, E-mail: virasabadash@gmail.com
}

\begin{abstract}
The adsorption of ortophosphoric acid by natural zeolite under static conditions has been investigated. The significant increasein zeolite sorption capacity was observed while interactionof zeolite and wastewaters with acid reaction.The thermodynamic calculations of the polymolecular adsorption have been carried out.
\end{abstract}

Keywords - adsorption, thermodynamics, phosphates, zeolite, BET isotherm.

\section{Introduction}

In the previous publication, the results of experimental studies of adsorption of phosphates with natural zeolite were presented. It was found that in the range of concentrations above 180 $\mathrm{mg} / \mathrm{dm}^{3}$ was a sharp increase of the sorption capacity of zeolite. However, the mechanism of this phenomenon was not clear [1]. therefore our task was to establish the thermodynamic probability of polymolecular adsorption of orthophosphoric acid by zeolite.

\section{Experimental}

A graphical interpretation of the experimental data on the adsorption of orthophosphoric acid with natural zeolite by the BET isotherm for the area of initial concentrations up to $375 \mathrm{mg} /$ $\mathrm{dm}^{3}$ is presented on Fig. 1. Therefore our task was to establish the thermodynamic probability of polymolecular adsorption of orthophosphoric acid by zeolite.

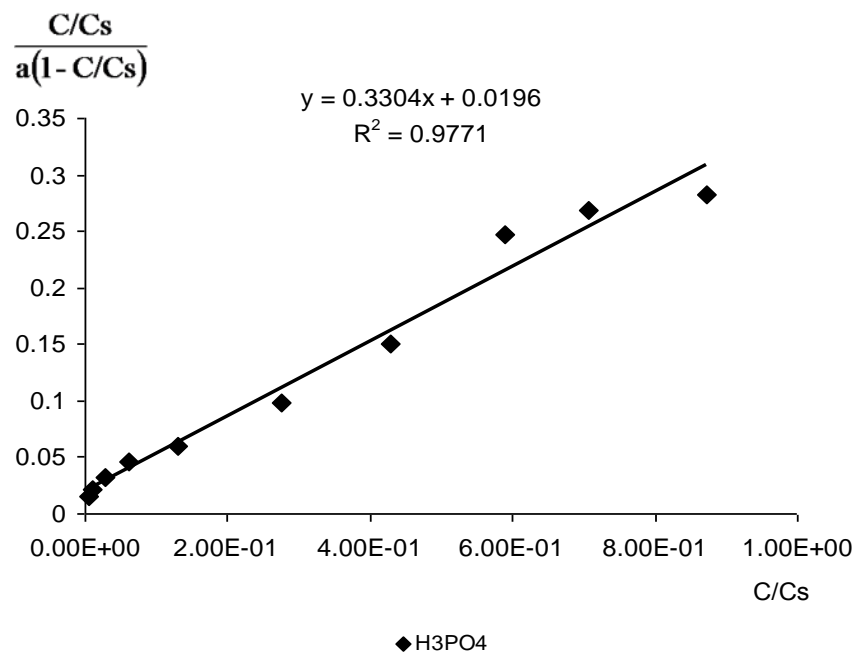

Fig. 1 - Linearized BET isotherm for adsorption of orthophosphoric acid by natural zeolite

Parameters of the BET equation for the phosphate adsorption process by $\quad \frac{1}{a_{m} K}=0.0196$; $\frac{K-1}{a_{m} K}=0.3304 ; \quad \mathrm{K}=0.99352416 ; \quad$ the maximum value of adsorption capacity on phosphates in multimolecular layer $\mathrm{a}_{\mathrm{m}}=51.35296$. Taking into account that the experimental data are well interpreted by the BET equation (determination coefficient $\mathrm{R}^{2}=0.9771$ ), we can assume formation in the volume of zeolite polyphosphates according to the equation:

$$
3 \mathrm{H}_{3} \mathrm{PO}_{4}+3 \mathrm{NaOH} \rightarrow \mathrm{Na}_{5} \mathrm{P}_{3} \mathrm{O}_{10}+7 \mathrm{H}_{2} \mathrm{O}
$$

To confirm the formation of polyphosphates in the volume of the sorbent, we have calculated the change in the standard Gibbs energy.

$$
\Delta G_{0}^{298}=\Delta \mathrm{H}_{0}^{298}-T \Delta S_{0}^{298} \frac{k J}{m o l}
$$

where $\Delta \mathrm{G}_{0}^{298}$ - Gibbs energy change, $\mathrm{J} /(\mathrm{mol}) ; \Delta \mathrm{S}_{0}^{298}$ - entropy change, $\mathrm{J} /($ mole $\cdot \mathrm{K})$; $\Delta \mathrm{H}_{0}{ }^{298}$ - enthalpy change, $\mathrm{J} /($ mole); T-absolute temperature, $\mathrm{K}$. 
The equilibrium state of the thermodynamic system is function of entropy and enthalpy factors. With the temperature $\mathrm{T}=\mathrm{dH} / \mathrm{dS}$, the system will be in equilibrium [2].

Entropy change we calculated according to the following equation:

$$
\Delta \mathrm{S}_{0}^{298}=\sum \Delta \mathrm{S}_{0 \text { п.р }}^{298}-\sum \Delta \mathrm{S}_{0}^{298} \text { вих }, \frac{k J}{\mathrm{~mol} \cdot \mathrm{K}}
$$

According to Hess's law we calculate the heat effect:

$$
\Delta H_{0}^{298}=\sum \Delta H_{0}^{298}-\sum \Delta H_{0}^{298}, \frac{k J}{m o l}
$$

Under standard conditions ( $\mathrm{T}=298 \mathrm{~K}$ ), the change in Gibbs energy also depends on the ratio of enthalpy and entropy factors [2]. Table 1.

The calculation of the thermodynamic parameters according to these equations are given in Computation result of thermodynamic parameters of polymolecular adsorption of phosphates

\begin{tabular}{|c|c|c|c|c|c|c|}
\hline $\begin{array}{c}\text { Type of } \\
\text { substance }\end{array}$ & Compound & $\begin{array}{c}\text { Stoichio- } \\
\text { metric } \\
\text { coefficient }\end{array}$ & $\begin{array}{c}\Delta \mathrm{H}^{\circ} 298, \\
\mathrm{~kJ} / \mathrm{mol}\end{array}$ & $\begin{array}{c}\Delta \mathrm{S}^{\circ} 298, \mathrm{~kJ} / \\
\text { mol K }\end{array}$ & $\begin{array}{c}\Delta \mathrm{G}, \mathrm{kJ} / \mathrm{mol} \\
\mathrm{t}=298 \mathrm{~K}\end{array}$ & $\begin{array}{c}\text { equilibrium } \\
\text { temperature, } \mathrm{K} \\
\text { teq=dH/dS }\end{array}$ \\
\hline $\begin{array}{c}\text { Reaction } \\
\text { product }\end{array}$ & $\mathrm{Na}_{5} \mathrm{P}_{3} \mathrm{O}_{10}$ & 1 & -4409 & 0.381 & - & - \\
\hline $\begin{array}{c}\text { Reaction } \\
\text { product }\end{array}$ & $\mathrm{H}_{2} \mathrm{O}$ & 7 & -285.8 & 0.07 & - & - \\
\hline Reagent & $\mathrm{NaOH}^{2}$ & 3 & -496 & 0.048 & - & - \\
\hline Reagent & $\mathrm{H}_{3} \mathrm{PO}_{4}$ & 3 & -1279 & 0.11 & - & - \\
\hline $\begin{array}{c}\text { Thermodynamic } \\
\text { parameters of } \\
\text { the reaction }\end{array}$ & - & - & -1084.6 & 0.397 & -1202.906 & -2731.9899 \\
\hline
\end{tabular}

The change of the standard Gibbs energy $\Delta \mathrm{G}<0$. This means that the reaction (1) can take place at room temperature. The increase in the reaction mixture temperature will increase the rate of chemical reaction.We can assume the possible formation of polyphosphates in zeolite pores.

\section{Conclusion}

In this paper the statics and thermodynamics of ortophosphoric acid adsorption on natural zeolire are given. Taking into account the results of thermodynamic calculations, it was confirmed that the absorption of ortophosphoric acid occurs via the mechanism of polymolecular adsorption.

\section{References}

[1] V. V. Sabahdash, J.M. Gumnitsky, A.M. Hyvlyud " Mechanism of phosphates sorption by zeolites depending on degree of their substitution for potassium ions,"Chemistry \& Chemical Technology, vol. 10, no. 2, June, pp. 235-240, 2016.

[2] V. V. Sabahdash, J.M. Gumnitsky, O.V. Lyuta, I. Pochapska " Thermodynamics of $\left(\mathrm{NH}_{4}{ }^{+}\right)$cation adsorption under static conditions," Chemistry \& Chemical Technology, vol. 12, no. 2, June, pp. 143-146, 2018. 